\title{
Production and characterization of niobium carbide coatings produced on tool steels by thermoreactive deposition/diffusion
}

\author{
Producción y caracterización de recubrimientos de carburo de niobio sobre aceros \\ para herramientas producidas mediante la deposición por difusión termorreactiva
}

\author{
F.E. Castillejo ${ }^{1,2}$ D.M. Marulanda ${ }^{3} \quad$ J.J. Olaya ${ }^{2}$
}

Recibido 11 de marzo de 2013, aceptado 17 de diciembre de 2013

Received: March 11, 2013 Accepted: December 17, 2013

\begin{abstract}
RESUMEN
En este trabajo se depositaron recubrimientos de carburo de niobio sobre aceros AISI M2, H13 y D2, utilizando la técnica de deposición por difusión termorreactiva. Los carburos se obtuvieron usando baños de sales compuestos por bórax fundido, ferroniobio, ferrovanadio y aluminio a una temperatura de $1.020{ }^{\circ} \mathrm{C}$ durante 4 horas. La presencia de los recubrimientos fue observada por microscopia electrónica de barrido. Las fases fueron determinadas usando difracción de rayos X, y se utilizó microdureza para determinar la dureza. El comportamiento electroquímico fue estudiado mediante curvas de polarización potenciodinámica para determinar la densidad de corriente de corrosión, y espectroscopia de impedancia electroquímica para determinar la resistencia a la polarización. Los resultados fueron comparados con las propiedades del sustrato sin recubrimiento y en general se observó mayor dureza y mejor resistencia a la corrosión en los recubrimientos producidos.
\end{abstract}

Palabras clave: Difusión, carburos de niobio, impedancia, aceros para herramientas, corrosión.

\begin{abstract}
In this work, niobium carbide coatings were deposited on AISI M2, H13, and D2 tool steels by thermoreactive deposition/diffusion. The carbides were obtained using salt baths composed of molten borax, aluminum, and ferroniobium at a temperature of $1020{ }^{\circ} \mathrm{C}$ for 4 hours. The coatings were observed via scanning electron microscopy. The phases were determined using X-ray diffraction, and Vickers indentation was used to determine the hardness. The electrochemical behavior was studied via potentiodynamic polarization curves to determine the rate of corrosion and electrochemical impedance spectroscopy was used to determine the resistance to polarization. The results were compared with the properties of the substrate without a coating, and in general, greater hardness and better corrosion resistance were observed with the coatings.
\end{abstract}

Keywords: Diffusion, niobium carbide, impedance, tool steels, corrosion.

1 Grupo de investigación en Ciencia e Ingeniería de Materiales. Universidad Santo Tomás. Calle 9 N 51-11. Bogotá, Colombia. E-mail: fabiocastillejo@usantotomas.edu.co

2 Departamento de Ingeniería Mecánica y Mecatrónica. Universidad Nacional de Colombia. Calle 45 No 26-85. Bogotá, Colombia. E-mail: jjolayaf@unal.edu.co

3 Grupo Research in Energy and Materials (REM). Universidad Antonio Nariño. Calle 22 S No 12 D-81. Bogotá, Colombia. E-mail:dmarulanda@uan.edu.co 


\section{INTRODUCTION}

Surface treatments are used to improve the tribological performance of many cutting tools, generally in machine elements that are subjected to high wear conditions. One of the surface treatments used is depositing layers of transition metal carbides or nitrides. These layers are commonly obtained using techniques such as physical vapor deposition (PVD) and chemical vapor deposition (CVD) [1-2]. One of the main limitations of these procedures is the use of complex equipment and high-vacuum conditions, which make their implementation expensive. A competitive and economical alternative is the application of hard coatings with good wear resistance by a thermoreactive deposition/diffusion process (TRD) [3] on substrates containing a carbon percentage higher than $0.3 \%$ by weight [4]. The layers deposited by this process exhibit good adhesion to the substrate, low coefficients of friction and excellent uniformity in thickness [5]. For this treatment, a salt bath composed of molten borax, aluminum, or ferrosilicon can be used as a reducing agent, along with carbide forming elements (CFE's), such as vanadium, chromium, titanium, and niobium [4]. The carbide layer is formed when the metal element dissolved in the salt bath has a relatively low carbide-formation energy and oxideformation energy greater than that of boron oxide $\left(\mathrm{B}_{2} \mathrm{O}_{3}\right)$ [6-7]. Otherwise, the boron atoms are not oxidized and remain free to diffuse into the steel matrix, which combine with the iron boride layers to form iron $\left(\mathrm{Fe}_{2} \mathrm{~B}\right.$ or $\left.\mathrm{FeB}\right)$ [8-9].

Several studies have developed binary metal carbides by the TRD process and have characterized their wear resistance, microstructure, and mechanical behavior. For example, several studies have focused on the production of $\mathrm{VC}$ and $\mathrm{NbC}$ coatings on substrates of AISI H13, AISI D2, and AISI M2 steels, reporting hardnesses up to $2300 \mathrm{HV}[3,5]$. Other investigations have studied the growth kinetics of niobium carbide on AISI 1040 steel [10], iron boride on AISI 4140 [11], and chromium carbide on AISI D2 steel [12]. These studies report that the thickness of the layers obtained for binary systems, such as $\mathrm{NbC}$ or $\mathrm{VC}$, depends on the treatment time and process temperature. Electrochemical studies have reported on forming iron boride using borax and aluminum on AISI S1, S2, and S3 steels by changing the percentage of manganese [13].
However, to the authors' knowledge, no studies have reported on the electrochemical behavior of niobium carbide coatings or its correlation with the chemical composition of the substrate.

\section{EXPERIMENTAL PROCEDURE}

Niobium carbide ( $\mathrm{NbC}$ ) coatings were deposited on substrates of AISI D2, M2, and H13 steels using samples $15 \mathrm{~mm}$ in diameter and $4 \mathrm{~mm}$ thick. The sample preparation included polishing using abrasive grinding papers from 220 to 1200 grit and ultrasonic cleaning with acetone.

The coatings were produced in a salt bath with a composition of 81 wt. $\% \mathrm{Na}_{2} \mathrm{~B}_{4} \mathrm{O}_{7}, 16$ wt. $\%$ Fe-Nb and $3 \mathrm{wt} . \% \mathrm{Al}$. The samples were heat treated at a temperature of $1020{ }^{\circ} \mathrm{C}$ for 4 hours in an electric furnace described elsewhere [14]. The phases present and the crystallographic orientation were visualized using $\mathrm{X}$-ray diffraction (XRD) on an $\mathrm{X}$-PertPro PANalytical instrument (configuration $\theta-2 \theta$ in a range of $10^{\circ}$ to $100^{\circ}, 45 \mathrm{kV}, 40 \mathrm{~mA}$, $\mathrm{CuK} \alpha$ monochromatic radiation, and wavelength of $1.56 \AA$ with a step size of $0.02^{\circ}$ ). The thickness of the coatings after being etched with $3 \%$ Vilella was determined using a Philips scanning electron microscope (SEM) with a voltage of $40 \mathrm{kV}$. Ten measurements were performed to obtain an average value. The hardness of the coatings was determined from measurements using the Vickers indenter with a load of $50 \mathrm{~g}$ in a Leco microhardness tester by making indentations transverse to the coating, which had been previously encapsulated in bakelite.

The electrochemical behavior of the coatings were studied by conducting potentiodynamic tests to obtain polarization curves and potentiostatic tests to obtain electrochemical impedance spectroscopy (EIS) using a Gamry Instruments 600 potentiostat. A three-electrode electrochemical cell was used in a volume of $100 \mathrm{ml}$ of a $3 \% \mathrm{NaCl}$ solution at room temperature. The working area was $0.196 \mathrm{~cm}^{2}$ using a platinum bar and a calomel electrode as the reference and auxiliary electrodes, respectively.

\section{RESULS AND DISCUSION}

Figure 1 shows the cross section SEM in the coatings obtained on the three steels used. It can be observed that the thicknesses exhibited excellent uniformity, 

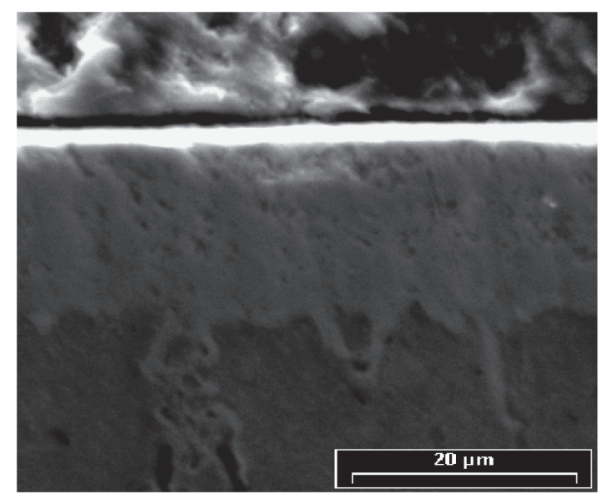

(a)
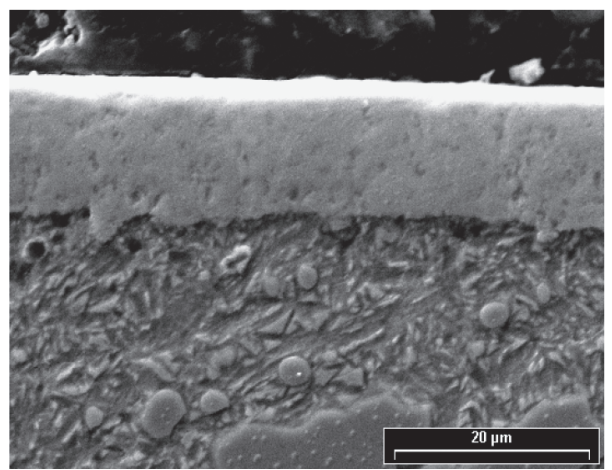

(b)

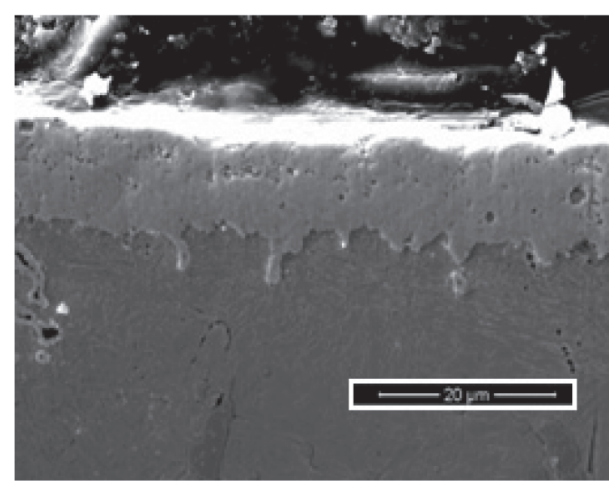

(c)

Figure 1. SEM micrographs of the coated steels: a) D2 b) M2, and c) H13.

with average values of $15.8 \pm 0.5 \mu \mathrm{m}, 12.6 \pm 0.2 \mu \mathrm{m}$, and $10.5 \pm 0.3 \mu \mathrm{m}$, for the AISI D2, M2 and H13 steel respectively.

Figure 2 shows the X-ray diffraction patterns for each of the treated steels. The $\mathrm{NbC}$ phase was confirmed for the three steels used as substrates, exhibiting in all cases high-intensity peaks for the (111), (200),

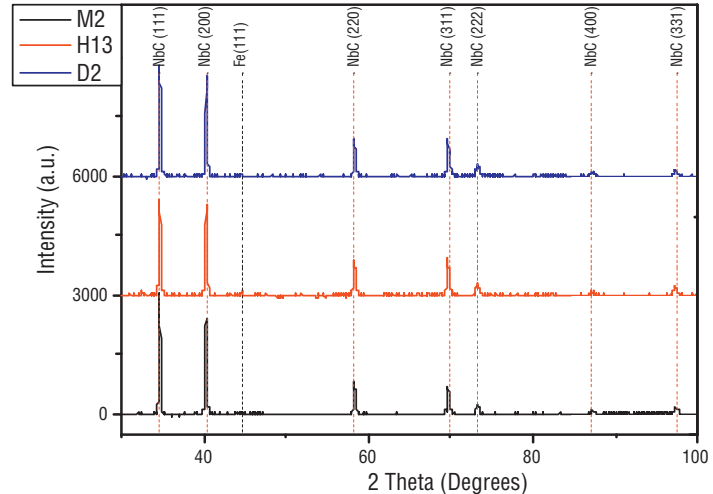

Figure 2. X-ray diffraction patterns of the coatings obtained.

and (311) crystallographic planes and low-intensity peaks for the (220), (222), (400), (331), (400), and (422) planes.

The type of layer formed can be explained by the free energies of carbide and oxide formation of the elements present in the salt bath. Niobium has a relatively low carbide formation energy of $-33.6 \pm 0.8 \mathrm{kcal}[15]$, whereas its free energy for the formation of $\mathrm{NbO}(-144 \mathrm{kcal})$ is greater than the free energy for the formation of $\mathrm{B}_{2} \mathrm{O}_{3}(-154 \mathrm{kcal})$ [16]. The layers are formed as a consequence of the direct combination of carbon in the steel with niobium dissolved in the bath. The composition of the coatings and their hardnesses are almost independent of the type of substrate and are not affected by the presence of the alloying elements of the steel.

The hardnesses obtained were $2266 \pm 83 \mathrm{HV}$ for AISI D2, $2241 \pm 74 \mathrm{HV}$ for AISI M2, and $2255 \pm 72 \mathrm{HV}$ for AISI H13. These hardness levels are in agreement with values reported for this type of carbide using the TRD technique $[3,5]$.

The corrosion rate of a coating-substrate system can be measured using current vs. potential curves, referred to as potentiodynamic polarization curves. Figure 3 shows the curves obtained for the three uncoated steels and those coated with $\mathrm{NbC}$, and the Table 1 summarizes the most important parameters obtained in this measurement. It can be observed that the resistance to corrosion of the coated steels decreased, which is clearly manifested in the decrease in the corrosion current and the increase 


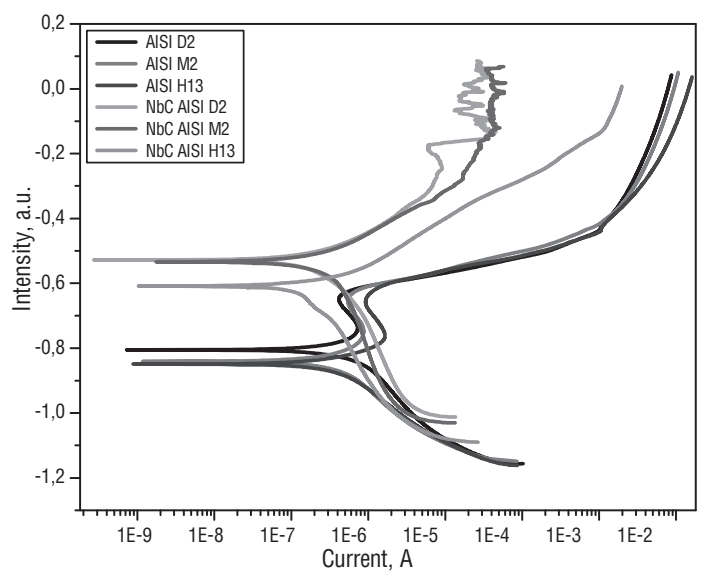

Figure 3. Tafel polarization curves of bare and coated steels.

Table 1. Tafel polarization parameters of the corrosion of bare and coated steels in $3 \% \mathrm{NaCl}$. (Corrosion current (Icor) and corrosion potential (Ecor)).

\begin{tabular}{|l|c|c|}
\hline \multicolumn{1}{|c|}{ Substrate } & Icorr (A) & $\begin{array}{c}\text { Ecorr } \\
(\mathbf{m V})\end{array}$ \\
\hline AISI D2 & $1.19 \mathrm{E}-06$ & -807 \\
\hline AISI M2 & $1.50 \mathrm{E}-06$ & -812 \\
\hline AISI H13 & $9.13 \mathrm{E}-07$ & -866 \\
\hline AISI D2 with NbC & $3.78 \mathrm{E}-07$ & -554 \\
\hline AISI M2 with NbC & $3.53 \mathrm{E}-07$ & -533 \\
\hline AISI H13 with NbC & $3.07 \mathrm{E}-07$ & -619 \\
\hline
\end{tabular}

in the corrosion potential of the coatings. The coating produced on the AISI D2 steel exhibited better performance than the coatings produced on the M2 and $\mathrm{H} 13$ steels.

The equivalent circuits used to fit the obtained EIS spectra are shown in the Figure 4 and were analyzed with the software Echem Analyst developed by Gamry Instruments.

For the uncoated steel (Figure 4a), a resistance $\mathrm{R}_{\mathrm{soln}}=\mathrm{R}_{\mathrm{u}}$ is proposed, which is the resistance of the solution connected in series with two elements in parallel: a constant phase element (CPE) pair where $\mathrm{Y}_{0}$ is the capacitor and alpha is the exponent. An alpha value of 1 indicates that the proposed element is completely capacitive and if less than 1 , indicates that the element has both capacitive and a resistive character; in the figure, $R_{p}$ represents the polarization resistance. In the case of the coated steel (Figure 4b),

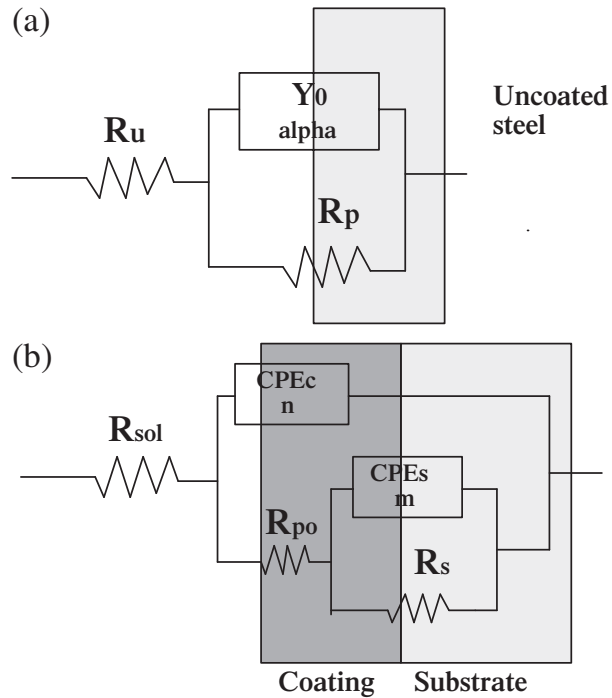

Figure 4. Equivalent circuits for the coatings in $3.5 \% \mathrm{NaCl}$ solution at different stages:

(a) bare steels and (b) coated steels.

$\mathrm{R}_{\text {soln }}=\mathrm{R}_{\mathrm{u}}$ appears again, with a CPE pair made up of $\mathrm{C}_{\mathrm{c}}$ that represents the coating capacitance; the value of the exponent $m$ again indicates the capacitive character of $\mathrm{C}_{\mathrm{c}}$. The resistance to charge transfer across the pores, $\mathrm{R}_{\mathrm{po}}$, also appears. A second CPE pair is included, made up of $\mathrm{C}_{\text {cor }}$, which represents the resistance to charge transfer across the interface $\left(\mathrm{R}_{\mathrm{cor}}\right)$, and the Helmholtz double-layer capacitance. The value of $n$ gives an indication of how capacitive this CPE pair is.

The impedance spectra obtained for exposure times of one hour, one day, two days, and 7 days in a 3\% $\mathrm{NaCl}$ solution are shown for the uncoated steels in Figure 5 and the values of the parameters obtained after fitting are summarized in the Table 2. The impedance spectra for the coated steel in the same condition than the uncoated steel, are shown in the Figure 6 and Table 3, respectively.

Figure 5 shows impedance values for the substrates between 5,000 and 50,000 Ohms with the presence of a time constant according to Figures $5 \mathrm{~b}, 5 \mathrm{~d}$ and $5 \mathrm{f}$. The steels coated with $\mathrm{NbC}$ have two time constants according to Figures $6 \mathrm{~b}, 6 \mathrm{~d}$, and $6 \mathrm{f}$, and these correspond to the coating and the steel time constant, denoted by $\tau_{c}$ and $\tau_{c o r r}$ respectively [17], where:

$$
\tau_{c}=R_{p o} C_{c} \quad \text { and } \quad \tau_{c}=R_{c o r} C_{c o r}
$$


(a)

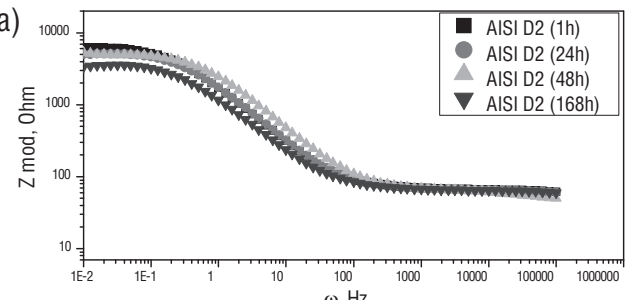

(c)

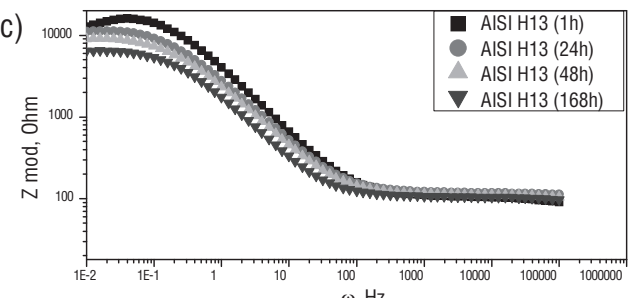

(e)

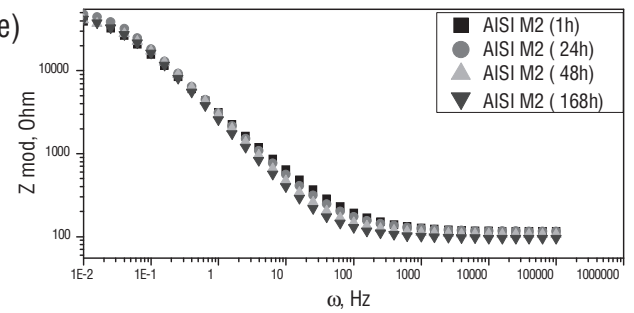

(b)

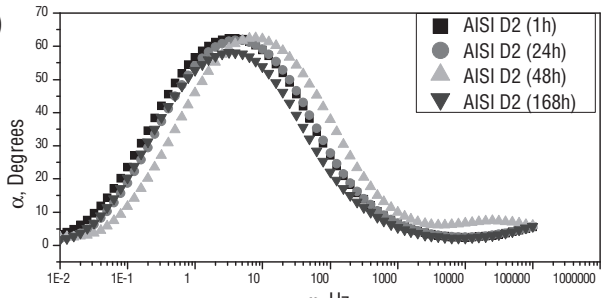

$\omega, \mathrm{Hz}$
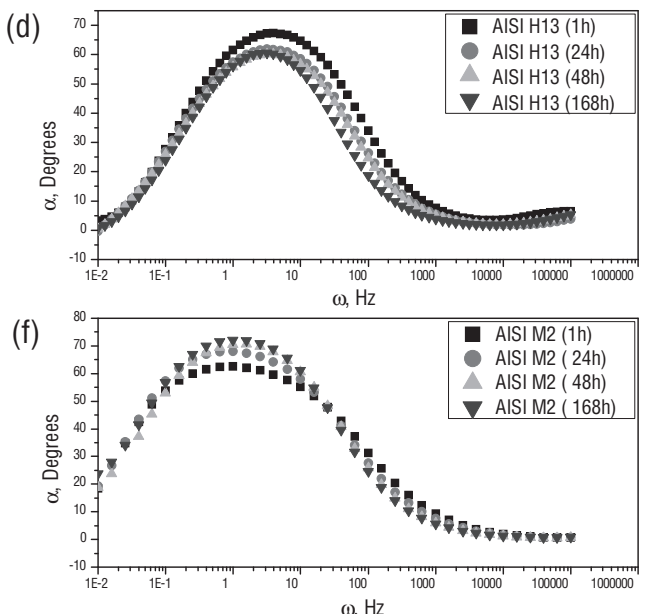

Figure 5. Bode plots of EIS spectra of bare AISI D2, M2, and H13 steels.

Table 2. Electrochemical impedance parameters on uncoated AISI D2, M2 and H13 steels.

\begin{tabular}{|c|c|c|c|c|c|c|}
\hline System & $\begin{array}{c}\text { Exposure } \\
\text { time }\end{array}$ & $\mathbf{R}_{\text {sol }}(\mathbf{o h m})$ & $\begin{array}{l}\mathbf{E}_{\text {corr }} \\
(\mathbf{m V})\end{array}$ & $\begin{array}{l}\mathbf{R}_{\text {polarization }} \\
\quad(\mathbf{o h m})\end{array}$ & $\begin{array}{c}\text { (CPE) } \mathrm{C} \\
\text { cor }\end{array}$ & alpha \\
\hline \multirow{4}{*}{ AISI D2 } & $1 \mathrm{~h}$ & 67 & \multirow{4}{*}{-789} & 6481 & $1.21 \mathrm{E}-04$ & 0.8 \\
\hline & $1 d$ & 65 & & 5290 & $1.14 \mathrm{E}-04$ & 0.81 \\
\hline & $2 \mathrm{~d}$ & 59 & & 5175 & $7.46 \mathrm{E}-05$ & 0.80 \\
\hline & $7 \mathrm{~d}$ & 64 & & 3698 & $1.75 \mathrm{E}-04$ & 0.79 \\
\hline \multirow{4}{*}{ AISI M2 } & $1 \mathrm{~h}$ & 116 & \multirow{4}{*}{-820} & 62980 & $8.08 \mathrm{E}-05$ & 0.73 \\
\hline & $1 \mathrm{~d}$ & 119 & & 61790 & $7.20 \mathrm{E}-05$ & 0.8 \\
\hline & $2 d$ & 109 & & 46050 & $7.29 \mathrm{E}-05$ & 0.83 \\
\hline & $7 \mathrm{~d}$ & 98 & & 48890 & $8.23 \mathrm{E}-05$ & 0.84 \\
\hline \multirow{4}{*}{ AISI H13 } & $1 \mathrm{~h}$ & 103 & \multirow{4}{*}{-842} & 16090 & 4.89E-05 & 0.84 \\
\hline & $1 \mathrm{~d}$ & 117 & & 11830 & 7.49E-05 & 0.81 \\
\hline & $2 \mathrm{~d}$ & 109 & & 9505 & $9.07 \mathrm{E}-05$ & 0.8 \\
\hline & $7 \mathrm{~d}$ & 104 & & 6574 & 1.17E-04 & 0.82 \\
\hline
\end{tabular}

It can be noted that the impedance of the coatings is greater (Table 3) with respect to the steels (Table 2). It can also be observed that the impedance decreases as the exposure time increases, which indicates that the coating has a porous character and that the electrolyte would penetrate the coating through the pores. It is clear that the porosity barely increases with exposure time, which indicates that it would take a long time for the electrolyte to penetrate finer defects, such as microcracks [18]. 
(a)

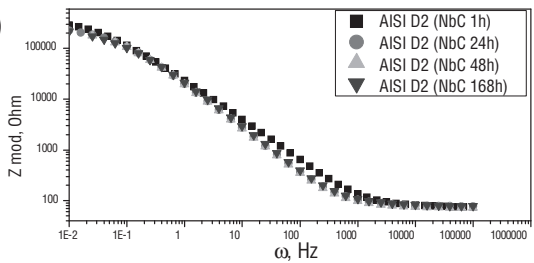

(c)

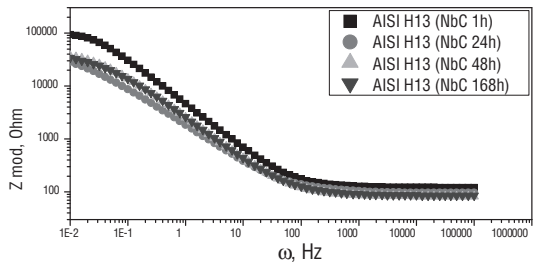

(e)

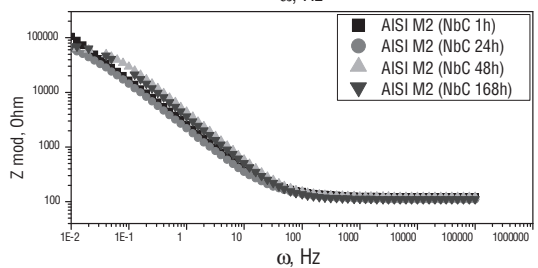

(b)

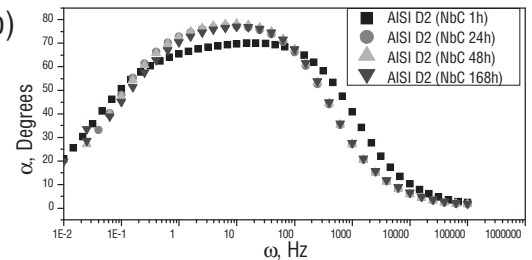

(d)

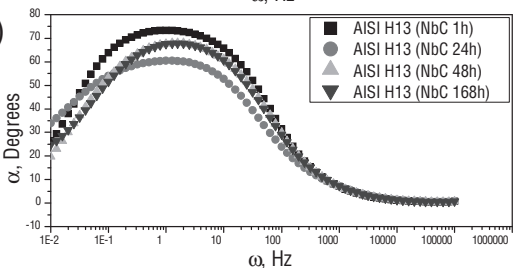

(f)

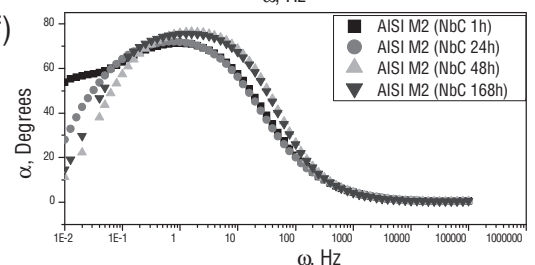

Figure 6. Bode plots of EIS spectra of the coated of NbC on AISI D2, M2, and H13 steels.

Table 3. Electrochemical impedance parameters on bare steels and coated steels.

\begin{tabular}{|c|c|c|c|c|c|c|c|c|}
\hline System & $\begin{array}{c}\text { Exposure } \\
\text { time }\end{array}$ & $\begin{array}{l}\text { Rsoln } \\
\text { (ohm) }\end{array}$ & $\begin{array}{l}\text { Rcor } \\
\text { (ohm) }\end{array}$ & Rpo(ohm) & (CPE) Ccor & $\mathbf{N}$ & $\begin{array}{c}\text { (CPE) } \\
\mathrm{Cc}\end{array}$ & $\mathbf{m}$ \\
\hline \multirow{4}{*}{$\mathrm{NbC}$ on $\mathrm{D} 2$} & $1 \mathrm{~h}$ & 74.79 & 184000 & 175400 & $8.30 \mathrm{E}-06$ & 0.74 & $9.03 \mathrm{E}-06$ & 0.81 \\
\hline & $1 d$ & 79.8 & 52330 & 196200 & $8.56 \mathrm{E}-05$ & 0.91 & 9.91E-06 & 0.88 \\
\hline & $2 d$ & 75.11 & 67410 & 181700 & 8.88E-05 & 0.97 & $9.83 \mathrm{E}-06$ & 0.89 \\
\hline & $7 \mathrm{~d}$ & 81.61 & 165400 & 135100 & 2.53E-05 & 0.62 & $9.01 \mathrm{E}-06$ & 0.88 \\
\hline \multirow{4}{*}{$\mathrm{NbC}$ on $\mathrm{M} 2$} & $1 \mathrm{~h}$ & 122.9 & 216000 & 10280 & 2.59E-06 & 0.35 & $8.39 \mathrm{E}-05$ & 0.83 \\
\hline & $1 d$ & 112.1 & 79180 & 9650 & $2.65 \mathrm{E}-10$ & 0.71 & $5.30 \mathrm{E}-05$ & 0.89 \\
\hline & $2 \mathrm{~d}$ & 123 & 80980 & 189.7 & $1.76 \mathrm{E}-06$ & 0 & $4.36 \mathrm{E}-05$ & 0.9 \\
\hline & $7 \mathrm{~d}$ & 112.1 & 94130 & 774.1 & $2.13 \mathrm{E}-06$ & 0 & 5.31E-05 & 0.89 \\
\hline $\mathrm{NbC}$ on $\mathrm{H} 13$ & $1 \mathrm{~h}$ & 120.8 & 123300 & 1230 & $2.10 \mathrm{E}-05$ & 0.81 & $2.41 \mathrm{E}-05$ & 0.88 \\
\hline
\end{tabular}

The carbide coating deposited on AISI D2 steel exhibited better electrochemical behavior, which can be due to one primary factor: its higher carbon content in the matrix caused the layer thickness which difficult the penetration of the electrolyte through the coating.

\section{CONCLUSIONS}

Niobium carbide coatings were obtained using the TRD technique and exhibited excellent uniformity in thickness and high hardness. The coating thickness obtained was proportional to the amount of carbon in the steel matrix used as a substrate. For this case, it was higher for AISI D2 and lower for AISI H13.

Potentiodynamic polarization curves showed a better performance for the $\mathrm{NbC}$ coating deposited on the D2 steel with more electropositive corrosion potentials, which might be because this coating had a lower percentage of porosity, which hampered the penetration of the electrolyte. EIS spectra confirmed the coating performance on the AISI D2 steel, and it was shown that the resistance of the coating was much higher than for the other steels. 
Furthermore, the phase-versus-frequency curves exhibited two time constants, for which the dielectric behavior of the coating is evident at high frequencies, and the dielectric behavior of the coating-substrate interface is evident at low frequencies.

\section{ACKNOWLEDGMENTS}

The authors would like to acknowledge the financial support of the Administrative Department of Science, Technology and Innovation-COLCIENCIAS, given through the project entitled "Ternary carbide coatings deposited with the TRD technique", code 1101-521-28337, under contract 338-2011.

\section{REFERENCES}

[1] J.L. He, Y.H. Lin and K.C. Chen. "Wear perfonmance of CAP- titanium nitride-coated high-speed steel in different dry sliding conditions". Wear. Vol. 208, pp. 36-41. 1997.

[2] Y.L. Su and W.H. Kao. "Optimum multilayer TiN-TiCN coatings for wear resistance and actual application”. Wear. Vol. 223, pp. 119130. 1998.

[3] C.K.N. Oliveira, R.M. Muñoz Riofano, and L.C. Castiletti. "Micro-abrasive wear test of niobium carbide layers produced on AISI H13 and M2 steels". Surf. Coat. Technol. Vol. 200, pp. 5140-5144. 2006.

[4] T. Arai and S. Harper. In: S.R. Lampman, T.B. Zorc (Eds). "Thermoreactive deposition/ diffusion Process”. ASM Handbook. ASM international, materials Park, OH, USA. Vol. 4, pp. 1000-1013. 1991.

[5] C.K.N. Oliveira, R.M. Muñoz Riofano and L.C. Castiletti. "Evaluation of hard coatings obtained on AISI D2 steel by thermo-reactive deposition treatment". Surf Coat. Technol. Vol. 201, pp. 1880-1885. 2006.

[6] T. Arai, H. Fujita, Y. Sugimoto and Y. Ohta. "Diffusion Carbide coatings Formed in molten bórax Systems". J. Mater. Eng. Vol. 9, pp. 183-189. 1987.

[7] T. Arai. "Tool materials and surfaces treatments. J. Mater. Process". Technol. Vol. 35, pp. 15-528. 1992.

[8] A.K. Sinha. In: S.R. Lampman, T.B. Zorc (Eds) "Boriding (Boronizing) of steels". ASM Handbook. ASM International.
Materials Park, OH, USA. Vol. 4, pp. 978999. 1991.

[9] S. Sen, I. Ozbek, U. Sen and C. Bindal. "Mechanical behavior of borides formed on borided cold work tool steel". Surf. Coat. Technol. Vol. 135, pp. 173-177. 2001.

[10] U. Sen. "Kinetics of niobium carbide coating produced on AISI 1040 steel by thermoreactive deposition technique". Mat. Chem. Phys. Vol. 86, pp. 189-194. 2004.

[11] S. Sen, U. Sen and C. Bindalb. "The growth kinetics of borides formed on boronized AISI 4140 steel”. Vacuum. Vol. 77, pp. 195-202. 2011.

[12] S. Sen. "A study on kinetics of CrxC-coated high-chromium steel by thermo-reactive diffusion technique". Vacuum. Vol. 79, pp. 63-70. 2005.

[13] H. Tavakoli and S.M. Mousavi Khoie. "An electrochemical study of the corrosion resistance of boride coating obtained by thermo-reactive diffusion". Mat. Chem. Phys. Vol. 124, pp. 1134-1138. 2010.

[14] F. Castillejo, D. Marulanda, O. Rodríguez and J.J. Olaya. "Electrical furnace for producing carbide coatings using the thermoreactive deposition/diffusion technique". Dyna. Vol. 170, pp. 192-197. 2011.

[15] W.L. Worrell and J. Chipman. "The Free Energies of Formation of the Vanadium, Niobium, and Tantalum Carbides". J. Phys. Chem. Vol. 68, pp. 860-866. 1964.

[16] T. Arai, K. Noburo and M. Masayoshi. "Diffusion layer of steel sufaces inmersed in fused borax baths containing varios kind of additives". Japan. Inst. Met. Vol. 39, pp. 247-255. 1935.

[17] C. Liu, Q. Bi, A. Leyland and A. Matthews. "An electrochemical impedance spectroscopy study of the corrosion behaviour of PVD coated steels in $0.5 \mathrm{~N} \mathrm{NaCl}$ aqueous solution: Part I. Establishment of equivalent circuits for EIS data modeling". Corros. Sci. Vol. 45, pp. 1243-1256. 2003.

[19] C. Liu, Q. Bi, A. Leyland and A. Matthews. "An electrochemical impedance spectroscopy study of the corrosion behaviour of PVD coated steels in $0.5 \mathrm{~N} \mathrm{NaCl}$ aqueous solution: Part II. EIS interpretation of corrosion behavior". Corros. Sci. Vol. 45, pp. 1257-1273. 2003. 